Article

\title{
Impact of Different Irrigant Agitation Methods on Bacterial Elimination from Infected Root Canals
}

\author{
Wajih Hage ${ }^{1}$, Roeland J. G. De Moor ${ }^{2,3,4}$, Désirée Hajj ${ }^{5}$, Germain Sfeir ${ }^{1}$, Dolla K. Sarkis ${ }^{5}$ \\ and Carla Zogheib ${ }^{6, *(\mathbb{D})}$ \\ 1 Department of Endodontics, School of Dentistry, Saint Joseph University, Beirut BP 17-5208, Lebanon \\ 2 Department of Conservative Dentistry and Periodontology, School of Dentistry, Medical University of \\ Vienna, Vienna 1090, Austria \\ 3 Austrian Cluster for Tissue Regeneration, Vienna 1090, Austria \\ 4 Department of Endodontology, Dental School, Ghent University, Ghent B9000, Belgium \\ 5 Microbiology Laboratory, School of Pharmacy, Saint Joseph University, Beirut BP 17-5208, Lebanon \\ 6 Head, Department of Endodontics, School of Dentistry, Saint Joseph University, Beirut BP 17-5208, Lebanon \\ * Correspondence: carla.zogheibmoubarak@usj.edu.lb or zogheibcarla@gmail.com; Tel.: +961-(1)-421-280
}

Received: 12 May 2019; Accepted: 10 June 2019; Published: 27 June 2019

\begin{abstract}
Activation techniques are essential for root canal disinfection but may result in incomplete removal of bacteria. The aim of our study was to assess the antibacterial action of sonically, ultrasonically and laser-activated irrigation and 5.25\% sodium hypochlorite ( $\mathrm{NaOCl}$ ) on Enterococcus faecalis in an infected tooth. Forty-four extracted mandibular premolars were mechanically prepared, sterilized, and inoculated with E. faecalis for 1 week. Bacterial counts after inoculation were evaluated in 4 randomly chosen teeth, remaining root canals were divided into 4 groups. Group A: laser-activated irrigation by photon-induced photoacoustic streaming, Group B: the sonic irrigation by EDDY, Group C: ultrasonic irrigation by EndoUltra, and Group D: 5.25\% NaOCl. Colony forming unit (CFU) counts were measured and Kolmogorov-Smirnov, Wilcoxon, Kruskal-Wallis and Mann-Whitney tests were used to determine differences. The mean of CFU was found to significantly decrease in group D, $2110 \pm 1015.93(p<0.001)$. Changes in measurement levels followed the same trend over time in groups A $27.40 \pm 30.15$, B $81.3 \pm 85.68$ and C $44.40 \pm 67.12(p=0.141)$. The average CFU after irrigation in all groups was significantly greater than 0 . Within the limitations of this study, all activation techniques were superior to $\mathrm{NaOCl} 5.25 \%$ in reducing $E$. faecalis from the infected tooth model.
\end{abstract}

Keywords: biofilm; laser-activated irrigation; root canal irrigation; sonic activation; ultrasonic activation

\section{Introduction}

The aim of root canal therapy is to reduce, as much as possible, the bacterial population colonizing the root canal system [1]. Many species are associated with pulpal and peri-radicular pathology and some are even in direct correlation with endodontic failure [2]. Persistent bacteria in root canal systems are found to be the major source of failure [2].

E. faecalis is commonly detected in asymptomatic persistent endodontic infections as it possesses various survival and virulence factors [3]. In a recent systematic review, a higher correlation was found with persistent intraradicular infections compared with untreated chronic apical periodontitis [4]. In this respect a continued research on E. faecalis elimination from the root canal system is advocated [5].

Basic chemo-mechanical preparation with different sodium hypochlorite $(\mathrm{NaOCl})$ concentrations leaves at least 40 to $60 \%$ of the initial bacterial counts in infected root canals and it is impossible to render root canals predictably free of cultivable bacteria [5-7]. The additional use of EDTA as a smear layer remover as well as an interappointment dressing with calcium hydroxide might increase 
the cases showing negative cultures [8]. This highlights the need for more effective strategies and the need to maximize the efficacy of irrigants that tend to induce better disinfection before filling the root canal systems [9]. In this regard, activation of irrigation techniques and delivery systems were introduced with the promise of optimizing the disinfection of root canals. An example of more recently introduced new activation techniques are: sonic activation (EDDY, VDW, Munich, Germany), ultrasonic activation (EndoUltra, MicroMega, Besancon, France) and laser activated irrigation with super short 50 microsecond pulse durations (PIPS, Fotona, Ljubljana, Slovenia).

EDDY (VDW, Munich, Germany) induces sonic oscillations using tips that are powered at a frequency of $6000 \mathrm{~Hz}$ by air scaler. The vibration produced is transferred to a polyamide tip that apparently does not damage the root canal walls [10].

EndoUltra (MicroMega, Besancon, France) is a hand-piece designed for intra-canal disinfection. It relies on ultrasonic technology with a frequency of $40 \mathrm{KHz}$, inducing acoustic streaming and cavitation. Its use aims to reduce bacterial levels through sonochemistry [11].

PIPS (Fotona, Ljubljana, Slovenia) is an acronym for photon-induced photoacoustic streaming. It can be described as an advanced laser activated irrigation (LAI) process using an Erbium laser $(2940 \mathrm{~nm})$ to pulse extremely low energy levels of laser light with short microsecond pulse duration to generate a photo-acoustic shock wave and where the tip is not positioned in the root canal itself [12]. It can stream irrigants throughout the entire root canal system $[13,14]$. It allows for better physical removal of an endodontic biofilm [15] as well as of a biofilm-mimicking hydrogel in an isthmus [16] when compared to ultrasonically activated irrigation.

To our knowledge, there is no study in the literature comparing the antibacterial effect of EDDY sonic, ENDOULTRA ultrasonic irrigation system with the PIPS laser activation tip 2 . Therefore, the aim of the present study was to evaluate the effectiveness of these recently introduced devices as compared to conventional irrigation in the reduction of E. faecalis populations.

\section{Materials and Methods}

The study protocol was approved by the "Ethics Committee" of Saint Joseph University Beirut (FMD158, 20-4-2018)

\subsection{Specimen Selection and Preparation}

Forty-four (4 groups of 10 teeth +4 negative controls) freshly extracted single rooted mandibular premolars were selected for this study. The premolar crowns were intact with no previous restoration. The presence of a single root canal was determined by preliminary radiographs taken in both mesio-distal and bucco-lingual directions. All premolars demonstrating fractured or immature apices were excluded from this study.

The included premolars were scaled on the external root surfaces. They were placed in a saline solution of $0.9 \%$ at $4{ }^{\circ} \mathrm{C}$ for $24 \mathrm{~h}$. Subsequently, samples were removed from the solution, and rinsed with distilled water.

After preparation of the opening cavity, the patency of each root canal was established using a 10 K-flexofile (Dentsply, Maillefer, Ballaigues, Switzerland) until it was visible through the apical foramen. Working length was established at $1 \mathrm{~mm}$ shorter than the apex. With this information in mind, the roots were further reduced in length, allowing a working length of $16 \mathrm{~mm}$. Root canals were enlarged as per the manufacturer's recommendation, sequentially up to a size of F2 Protaper Gold (Dentsply ${ }^{\circledR}$, Maillefer, Switzerland). Alternatively, irrigation was performed with $5.25 \% \mathrm{NaOCl}$ (Clorox, Vernon, CA, USA) during the whole shaping process with a $3 \mathrm{~mL}$ syringe and a $27 \mathrm{G}$ lateral side ject needle (Transcodent GmbH \&Co., Sulzer, Switzerland) $(0.05 \mathrm{~mL} / \mathrm{sec})$. A volume of $3 \mathrm{~mL}$ distilled water was used after the last $\mathrm{NaOCl}$ irrigation in order to remove the remaining solution. Then, a last flush of EDTA 17\% (Vista, WI, USA) was used as a final irrigation $(3 \mathrm{~mL}, 0.05 \mathrm{~mL} / \mathrm{sec}$ for $1 \mathrm{~min})$. Each root canal was dried with sterile paper points. 
The foramen was sealed with resin-epoxy material in order to prevent bacterial leakage and teeth were mounted in silicone impression material blocks (3M ESPE Express STD, MN, USA).

The specimens were then sterilized for $20 \mathrm{~min}$ at $121^{\circ} \mathrm{C}$ at 20 psi pressure (W\&H-Lisa, Bürmoos, Austria).

\subsection{Specimen Contamination}

E. faecalis derived from ATCC 29212 was obtained from the microbiologic department of Saint Joseph university and cultured aerobically on blood agar at $35^{\circ} \mathrm{C}$ for $48 \mathrm{~h}$. Colonies were then grown in Brain Heart Infusion (BHI) broth at $37^{\circ} \mathrm{C}$ for $24 \mathrm{~h}$. Inoculum was prepared in sterile BHI broth and turbidity was set to $0.5 \mathrm{McF}$ arland corresponding to approximately $1.5 \times 10^{8}$ colony forming units per milliliter $(\mathrm{CFU} / \mathrm{mL})$. A total of $10 \mu \mathrm{l}$ of the culture was immediately inoculated in the root canals. Teeth were placed in sterile cups and incubated at $37^{\circ} \mathrm{C}$ for 7 days. Four root canals were randomly selected for enumeration of E. faecalis directly after inoculation. Inoculum was renewed every day following incubation to ensure maintenance of the culture viability.

\subsection{Protocols for Irrigant Activation}

After the incubation period, canal roots were divided into 4 groups:

Group A $(\mathrm{n}=10)$-laser-activated irrigation with photon-induced photoacoustic streaming (PIPS ${ }^{\circledR}$ ): a 2.940 nm Er:YAG laser (Light Walker DT, Fotona, Ljubljana, Slovenia) equipped with a H14 handpiece (LightWalker Handpiece, Fotona, Ljubljana, Slovenia) holding a conical PIPS tip ( $9 \mathrm{~mm}$ long; $600 \mu \mathrm{m}$ diameter) was used to activate the irrigant. The fiber tip was positioned at the entrance of the canal. The pulse energy $0.02 \mathrm{~J}$, the frequency was $15 \mathrm{~Hz}$, and the pulse duration was 50 microseconds. The irrigation protocol was as follows: the canal was flushed with $3 \mathrm{~mL}$ irrigant $(0.05 \mathrm{~mL} / \mathrm{sec})$ using a 27G lateral side ject Needle (Transcodent GmbH and Co. KG, Kiel, Germany) while activating. The procedure was repeated 3 times. A total of $3 \mathrm{~mL}$ of distilled water followed the irrigation protocol.

Group B ( $\mathrm{n}=10)$-sonically activated irrigation with EDDY (VDW, Munich, Germany): the tip made of flexible polyamide with a size of 25.04, driven by an air hand piece (AirScaler-W\&H, Lisa, Bürmoos, Austria) was moved up and down over a distance of $3 \mathrm{~mm}$ starting $1 \mathrm{~mm}$ from the apical terminus without pressure according to the manufacturer's recommendations $(6000 \mathrm{~Hz}, 0.3 \mathrm{mPa} / 3 \mathrm{bar})$ for $30 \mathrm{~s}$. The procedure was repeated 3 times. In between each activation cycle, the canal was flushed with $3 \mathrm{~mL}$ irrigant $(0.05 \mathrm{~mL} / \mathrm{sec})(\mathrm{NaOCl} 5.25 \%)$ using a $27 \mathrm{G}$ needle.

Group C ( $\mathrm{n}=10)$-ultrasonic irrigation with EndoUltra (MicroMega, Besancon, France): this cordless device oscillates an activator tip of $15 / 0.2$ at $40 \mathrm{KHz}$, the system was performed using $5 \mathrm{~mL}$ of $5.25 \% \mathrm{NaOCl}$ solution in a vertical movement over a distance of $3 \mathrm{~mm}$ without pressure for $30 \mathrm{~s} \mathrm{starting}$ $1 \mathrm{~mm}$ from the apical terminus according to the instructions of the manufacturer. The procedure was repeated 3 times. In between each activation cycle, the canal was flushed with $3 \mathrm{~mL}$ irrigant ( $\mathrm{NaOCl} 5.25 \%$ ) using a 27G needle.

Group D ( $\mathrm{n}=10)$ - conventional irrigation: a 27G needle with a lateral exit was applied without pressure in a vertical movement of $3 \mathrm{~mm}$, at $1 \mathrm{~mm}$ from the apical end of the preparation, using a 27G lateral side ject needle (Transcodent $\mathrm{GmbH} \& \mathrm{Co}$. KG, Kiel, Germany) of $3 \mathrm{~mL}$ of $\mathrm{NaOCl} 5.25 \%$ for $5 \mathrm{~min}(0.05 \mathrm{~mL} / \mathrm{sec})$. This constituted the control group.

Following irrigation, after drying the root canals, E. faecalis bacterial count was evaluated by placing a sterile paper point into each canal for $5 \mathrm{~min}$. Paper points were then placed in $500 \mu \mathrm{L}$ sterile BHI broth for $15 \mathrm{~min}$. After mixing by vortex, $50 \mu \mathrm{L}$ of the liquid medium was serially diluted in sterile BHI broth and plated on blood agar. Culture media was placed at $37^{\circ} \mathrm{C}$ for $48 \mathrm{~h}$. Colonies were counted and confirmed by colony morphology observation on blood agar and Gram staining.

Non-inoculated root canals were similarly incubated and cultured to serve as negative control $(n=4)$.

\subsection{Statistical Analysis}

The Statistical Package Software for Social Science (SPSS for Windows, Version 22.0, Chicago, IL, USA) was used to perform the statistical analysis. The level of significance was set at $p \leq 0.05$. 
Kolmogorov-Smirnov tests were conducted to evaluate the normality distribution of continuous variables. Wilcoxon tests were performed to compare CFU before and after irrigation for each group. The variation of CFU after irrigation was compared between the 4 groups using Kruskal-Wallis tests, followed by Mann-Whitney tests.

\section{Results}

In Table 1, the mean and SD of the CFU in each group are shown. The data are also represented in box plots in Figure 1. The CFU has decreased significantly after canal irrigation with the conventional method $(p<0.001)$, PIPS $(p<0.001)$, EDDY $(p<0.001)$ and EndoUltra $(p<0.001)$.

Table 1. Mean and Standard deviation of colony forming unit (CFU) in each group.

\begin{tabular}{cccccc}
\hline & Conventional & PIPS & EDDY & Endoultra & $-p$-Value \\
\hline Control groups & $1900000 \pm 0.000$ & $1700000 \pm 0.000$ & $1500000 \pm 0.000$ & $1500000 \pm 0.000$ & 1.000 \\
After irrigation & $2110 \pm 1015.93^{\mathrm{b}}$ & $27.40 \pm 30.15^{\mathrm{a}}$ & $81.30 \pm 85.68^{\mathrm{a}}$ & $44.40 \pm 67.12^{\mathrm{a}}$ & $<0.001$ \\
$-p$-value & $<0.001$ & $<0.001$ & $<0.001$ & $<0.001$ & \\
Percentage of decrease & $99.889 \% \pm 0.053^{\mathrm{a}}$ & $99.998 \% \pm 0.002^{\mathrm{b}}$ & $99.994 \% \pm 0.006^{\mathrm{b}}$ & $99.997 \% \pm 0.004^{\mathrm{b}}$ & $<0.001$ \\
\hline
\end{tabular}

$\left({ }^{\mathrm{a}}, \mathrm{b}\right.$ Different letters indicate the presence of significant difference between irrigation groups).

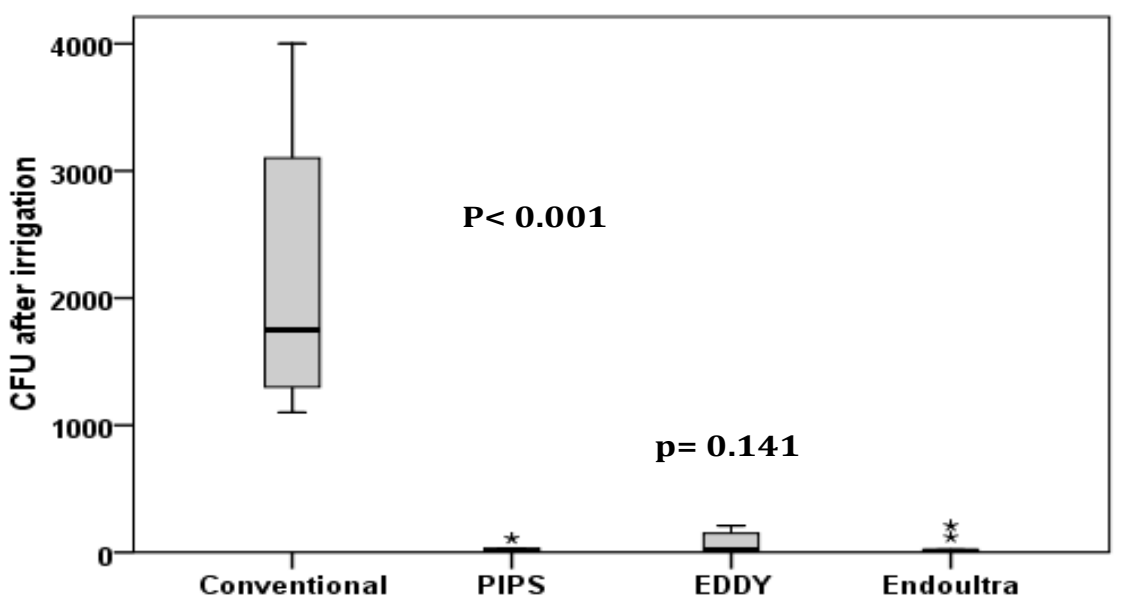

Figure 1. Distribution of CFU among groups. The decrease of CFU was significantly lower after conventional irrigation $(p<0.001)$. However, no significant difference was found between photon-induced photoacoustic streaming (PIPS), EDDY and EndoUltra $(p=0.141)$.

The decrease of CFU was significantly lower after conventional irrigation $(p<0.001)$. The effect was more pronounced with the laser activated irrigation but changes in measurements between groups followed the same trend with no statistically differences between PIPS, EDDY and EndoUltra $(p=0.141)$.

The percentage of decrease was high but significantly different from $100 \%(p<0.05)$, which means that no irrigation technique can completely eliminate bacterial colonies of $E$. faecalis from root canals.

\section{Discussion}

Disinfection of the root canal system is a necessity during the chemomechanical preparation. Multiple shaping instruments are available with satisfactory mechanical and physical properties, though not capable of cleaning entirely the root canal wall $[17,18]$. A chemical disinfection of the root canal system is mandatory for the removal of the majority of bacterial populations that are present in infected root canals. Next to the amount of uninstrumented root canal wall areas anatomical complexities found in the root canal system, especially in the apical third, that cannot be reached by instruments, require cleaning and disinfection with irrigation solutions [19]. A sodium hypochlorite 
solution (1-5.25\%) used as root canal irrigant is considered the gold standard for root canal cleaning and disinfection [20].

It is very efficient in removing the infected pulpal tissues due to its proteolytic properties. It is known to be very effective against a large spectrum of bacteria, viruses, fungi and other microorganisms [21]. Moreover, some recent studies have shown that activating the sodium hypochlorite solution is also very effective in optimizing its capabilities [22].

The aim of our study was to assess the influence of three activation techniques in removing the bacterial population of E. faecalis from the root canal, compared to conventional needle syringe irrigation. The null hypothesis that the activated irrigation groups do not differ from each other in antimicrobial efficacy is not rejected.

This study was based on mandibular premolars with a single root canal. The samples were standardized in order to reduce the bias of the study. All the working lengths were set at $16 \mathrm{~mm}$. The final apical taper was $8 \%$ and the final apical diameter for all the selected premolars was $0.25 \mathrm{~mm}$.

In the present study, we tried to simulate the typical clinical scenario of the canal surinfection by renewing the inoculum daily for a week, as it is well known that when a tooth is infected, the pathology can easily amplify if the cause is not treated $[23,24]$.

Root canal infection is typically caused by multiple microorganisms forming a well-organized biofilm [25]. The choice of E. faecalis, as a unique bacterium, was based on its behavior in infected root canals. It endures a prolonged period of nutritional deprivation. It binds to dentin and invades dentinal tubules. It alters the host response and suppresses the action of lymphocytes. E. faecalis possesses lytic enzymes, cytolisin, aggregation substances, pheromones and lipoteichoic acids $[3,26]$. Based on what preceded, E. faecalis can persist in the root canal system and peri-radicular lesions and is a common cause of failure of endodontically treated teeth [27].

The present set-up is one of the most common biofilm model systems [16]. In this respect, sampling after implementation of the investigated irrigation protocols was done with a sterile paper point. Loosening biofilm bacteria was not performed with a scraping action of a file along the root canal walls, though the paper point was left $5 \mathrm{~min}$ in the root canal [28].

Our results indicated that all activation techniques used in this study significantly lowered the CFU of E. faecalis compared to the initial ratio. Additionally, the conventional needle protocol is significantly less efficient in eliminating E. faecalis, when compared to the three irrigant agitation modalities. This result may be explained by the fact that conventional needle syringe irrigation provides far lower fluid dynamics as compared to the investigated activation techniques [14] and this also despite of the irrigation period of $5 \mathrm{~min}$. There is also no increase of the $\mathrm{NaOCl}$ solution reaction rate which is seen with activation of irrigation solutions [29]. Furthermore, its use at $3 \mathrm{~mm}$ of the apical foramen may also induce a vapor-lock effect, therefore lowering the efficiency of $\mathrm{NaOCl}$ [30], as shown in a number of recent studies [31-33]. This was avoided by placing the needle at $3 \mathrm{~mm}$ from the apical end of the preparation length.

No statistically significant differences regarding the decrease of the CFU in the root canals activated by EDDY, EndoUltra and PIPS were found. This is consistent with a number of recent studies [34-36].

In general, it is believed that sonic activation is seemingly less effective than the use of ultrasound, as a more velocious fluid stream is induced with the latter [37-40]. Furthermore, instrument size, tip diameter, instrument taper, confinement of the instrument within the confines of the canal and the type of irrigant, all do have an influence on the cleaning and disinfection efficacy associated with enhanced fluid streaming. Although EDDY is categorized as a sonically activated system, the cleaning efficacy when evaluating the removal of a biofilm mimicking hydrogel (BMH) out of an isthmus, appeared to be at the same level as the PIPS approach [41]. In the same investigation, EDDY activation resulted in a higher removal of this BMH as compared to ultrasonic active irrigation (UAI) with the Irrisafe. Where sonic activation in general is described with a one node pattern, high speed imaging showed the EDDY moving in a circular direction and with the instrument having an additional extra movement of the most apical part of the tip, as is seen with the moving trunk of an elephant [42]. 
This specific agitation pattern also explained the higher cleaning efficacy than that of the EndoActivator in the latter investigations.

The literature regarding EndoUltra is limited. EndoUltra resulted in a more effective smear layer removal than the EndoActivator [43]. At this moment no further information is found on the EndoUltra. No studies on the antibacterial action are published to our knowledge.

The mechanical effect of LAI was shown to be stronger than ultrasonic activation during the physical removal of a biofilm-mimicking hydrogel (water as irrigant) [14] and of a dual species biofilm (S. mutans and E. faecalis) (saline as irrigant) [15], which was attributed to the extremely turbulent action of the irrigation solutions activated with a pulsed erbium laser; consequently, when $\mathrm{NaOCl}$ was used as an irrigant, the reductions were superior to the results obtained with saline and both LAI and ultrasound did no show significant differences any more [15]. 15Although not statistically significant, together with data from other studies the final number of bacteria left was lower, the final amount of reduction was higher or more negative samples were seen with LAI [31,34,36,44-48]. The same phenomenon is also seen in the present study. All irrigant activation techniques may be associated with apical irrigant extrusion causing post-operative undesirable outcomes. Data from previous in vivo investigation [49] indicated that all irrigation protocols gave satisfactory results in meaning of post-operative pain, without any significant difference noted with PIPS as a final irrigation technique.

In this study all three activation techniques resulted in similar antibacterial efficacy, demonstrating that the specific movement of the EDDY during irrigant activation brought the sonic approach at the same level as UAI with UltraEndo and LAI with the PIPS approach. Laser activation of $5.25 \%$ sodium hypochlorite significantly improved the cleaning of intracanal E. Faecalis followed by ultrasonic, and sonic activation with no statistical difference between the groups.

Further research is needed in order to evaluate the impact of specific fluid streaming patterns during irrigant activation on the interaction with endodontic biofilms.

\section{Conclusions}

Although none of the treatment regimens were able to reliably render canals sterile under the conditions used, laser activation of $5.25 \%$ sodium hypochlorite significantly improved the cleaning of intracanal Enterococcus Faecalis followed by ultrasonic, and sonic activation with no statistical difference between the groups. The impact of irrigant streaming related to different types of sonic and ultrasonic activation on biofilm interaction and removal needs further investigation.

Author Contributions: Conceptualization, W.H. and C.Z.; Investigation, W.H., D.H., G.S., and C.Z.; Methodology, W.H. and D.H.; Project administration, C.Z.; Supervision, D.K.S., C.Z.; Validation, C.Z. and D.K.S.; Visualization, W.H. and C.Z.; Writing—original draft, W.H.; G.S. Writing—review and editing, R.J.G.D.d.M., C.Z.

Funding: This research received no external funding.

Conflicts of Interest: The authors declare no conflict of interest.

\section{References}

1. Siqueira, J.F.; Rôças, I.N. Clinical implications and microbiology of bacterial persistence after treatment procedures. J. Endod. 2008, 34, 1291-1301. [CrossRef] [PubMed]

2. Nair, P.N.; Henry, S.; Cano, V.; Vera, J. Microbial status of apical root canal system of human mandibular first molars with primary apical periodontitis after "one-visit" endodontic treatment. Oral Surg. Oral Med. Oral Pathol. Oral Radiol. Endod. 2005, 99, 231-252. [CrossRef] [PubMed]

3. Stuart, C.H.; Schwartz, S.A.; Beeson, T.J.; Owatz, C.B. Enterococcus faecalis: Its role in root canal treatment failure and current concepts in retreatment. J. Endod. 2006, 32, 93-98. [CrossRef] [PubMed]

4. Zhang, C.; Du, J.; Peng, Z. Correlation between Enterococcus faecalis and Persistent Intraradicular Infection Compared with Primary Intraradicular Infection: A Systematic Review. J. Endod. 2015, 41, 1207-1213. [CrossRef] [PubMed] 
5. Sjögren, U.; Figdor, D.; Persson, S.; Sundqvist, G. Influence of infection at the time of root filling on the outcome of endodontic treatment of teeth with apical periodontitis. Int. Endod. J. 1997, 30, 297-306. [CrossRef] [PubMed]

6. Shuping, G.B.; Orstavik, D.; Sigurdsson, A.; Trope, M. Reduction of intracanal bacteria using nickel-titanium rotary instrumentation and various medications. J. Endod. 2000, 26, 751-755. [CrossRef] [PubMed]

7. McGurkin-Smith, R.; Trope, M.; Caplan, D.; Sigurdsson, A. Reduction of intracanal bacteria using GT rotary instrumentation, 5.25\% NaOCl, EDTA, and $\mathrm{Ca}(\mathrm{OH}) 2$. J. Endod. 2005, 31, 359-363. [CrossRef]

8. Siqueira, J.F., Jr.; Guimarães-Pinto, T.; Rôças, I.N. Effects of chemomechanical preparation with $2.5 \%$ sodium hypochlorite and intracanal medication with calcium hydroxide on cultivable bacteria in infected root canals. J. Endod. 2007, 33, 800-805. [CrossRef]

9. Versiani, M.A.; De-Deus, G.; Vera, J. 3D mapping of the irrigated areas of the root canal space using microcomputed tomography. Clin. Oral Investig. 2015, 19, 859-866. [CrossRef]

10. Macedo, R.; Verhaagen, B.; Rivas, D.F.; Versluis, M.; Wesselink, P.; Van Der Sluis, L. Cavitation measurement during sonic and ultrasonic activated irrigation. J. Endod. 2014, 40, 580-583. [CrossRef]

11. Lloyd, A.; Navarrete, G.; Marchesan, M.A.; Clement, D. Removal of calcium hydroxide from Weine Type II systems using photon-induced photoacoustic streaming, passive ultrasonic, and needle irrigation: A microcomputed tomography study. J. Appl. Oral Sci. 2016, 24, 543-548. [CrossRef] [PubMed]

12. Olivi, G.; DiVito, E. Advanced Laser-Activated Irrigation: PIPS TM Technique and Clinical Protocols. In Lasers in Endodontics: Scientific Background and Clinical Applications, 1st ed.; Olivi, G., De Moor, R., DiVito, E., Eds.; Springer International Publishing Switzerland: Cham, Switzerland; Heidelberg, Germany; New York, NY, USA; Dordrecht, The Netherlands; London, UK, 2016; pp. 219-291.

13. Lloyd, A.; Uhles, J.P.; Clement, D.J.; Garcia-Godoy, F. Elimination of intracanal tissue and debris through a novel laser-activated system assessed using high-resolution micro-computed tomography: A pilot study. J. Endod. 2014, 40, 584-587. [CrossRef] [PubMed]

14. Swimberghe, R.C.D.; De Clercq, A.; De Moor, R.J.G.; Meire, M.A. Efficacy of sonically, ultrasonically and laser-activated irrigation in removing a biofilm-mimicking hydrogel from an isthmus model. Int. Endod. J. 2019, 52, 515-523. [CrossRef] [PubMed]

15. De Meyer, S.; Meire, M.A.; Coenye, T.; De Moor, R.J. Effect of laser-activater irrigation on biofilms in artificial root canals. Int. Endod. J. 2017, 50, 472-479. [CrossRef]

16. Swimberghe, R.C.D.; Coenye, T.; De Moor, R.J.G.; Meire, M.A. Biofilm model systems for root canal disinfection: A literature review. Int. Endod. J. 2019, 52, 604-628. [CrossRef] [PubMed]

17. Aguiar, C.M.; Mendes, D.A.; Câmara, A.C.; de Figueiredo, J.A.P. Assessment of canal walls after biomechanical preparation of root canals instrumented with protaper universal rotaty system. J. Appl. Oral Sci. 2009, 17, 590-595. [CrossRef] [PubMed]

18. Peters, O.A.; Peters, C.I.; Schönenberger, K.; Barbakow, F. ProTaper rotary root canal preparation: Effects of canal anatomy on final shape analysed by micro CT. Int. Endod. J. 2010, 36, 86-92. [CrossRef]

19. Plotino, G.; Cortese, T.; Grande, N.M.; Leonardi, D.P.; Di Giorgio, G.; Testarelli, L.; Gambarini, G. New Technologies to Improve Root Canal Disinfection. Braz. Dent. J. 2016, 27, 3-8. [CrossRef] [PubMed]

20. Zehnder, M. Root canal irrigants. J. Endod. 2006, 32, 389-398. [CrossRef] [PubMed]

21. Virdee, D.; Seymour, D.; Farnell, G.; Bhakta, S. Efficacy of irrigant activation techniques in removing intracanal smear layer and debris from mature permanent teeth: A systematic review and meta-analysis. Int. Endod. J. 2018, 22, 655-670. [CrossRef]

22. Vertucci, F.J. Root canal anatomy of the human permanent teeth. Oral Surg. Oral Med. Oral Pathol. Oral Radiol. Endod. 1984, 58, 589-599. [CrossRef]

23. Siqueida, J.F.; Rôças, I. Present status and future directions in endodontic microbiology. Endod. Top. 2014, 30, 3-22. [CrossRef]

24. Jhajharia, K.; Parolia, A.; Shetty, K.V.; Mehta, L.K. Biofilm in endodontics: A review. J. Int. Soc. Prev. Community. Dent. 2015, 5, 1-12. [CrossRef] [PubMed]

25. Love, R.M. Enterococcus faecalis - a mechanism for its role in endodontic failure. Int. Endod. J. 2001, 34, $399-405$. [CrossRef] [PubMed]

26. Nair, P.N. On the causes of persistent apical periodontitis: A review. Int. Endod. J. 2006, 39, $249-281$. [CrossRef] [PubMed] 
27. Boutsioukis, C.; Gogos, C.; Verhaagen, B.; Versluis, M.; Kastrinakis, E.; Van Der Sluis, L.W.M. The effect of root canal taper on the irrigant flow: Evaluation using an unsteady Computational Fluid Dynamics model. Int. Endod. J. 2010, 43, 909-916. [CrossRef] [PubMed]

28. Jaramillo, D.; Aguilar, E.; Arias, A.; Ordinola-Zapata, R.; Aprecio, R.M.; Ibarrola, J.L. Root canal disinfection comparing conventional irrigation vs photon-induced photoacoustic streaming (PIPS) using a buffered $0.5 \%$ sodium hypochlorite solution. Evid. Based Endod. 2016, 1, 1-6. [CrossRef]

29. Macedo, R.G.; Wesselink, P.R.; Zaccheo, F.; Fanali, D.; Van Der Sluis, L.W.M. Reaction rate of $\mathrm{NaOCl}$ in contact with bovine dentine: Effect of activation, exposure time, concentration and pH. Int. Endod. J. 2010, 43, 1108-1115. [CrossRef]

30. Zhu, X.; Yin, X.; Chang, J.W.; Wang, Y.; Cheung, G.S.; Zhang, C. Comparison of the Antibacterial Effect and Smear Layer Removal Using Photon-Initiated Photoacoustic Streaming Aided Irrigation Versus a Conventional Irrigation in Single-Rooted Canals: An In Vitro Study. Photomed. Laser Surg. 2013, 8, 3531. [CrossRef]

31. Peters, O.; Bardsley, S.; Fong, J.; Pandher, G.; Divito, E. Disinfection of root canals with photon-intiated photoacoustic streaming. J. Endod. 2011, 37, 1008-1012. [CrossRef]

32. Oridinola-Zapata, R.; Bramante, C.M.; Aprecio, R.M.; Handysides, R.; Jaramillo, D.E. Biofilm removal of $6 \%$ sodium hypochlorite activated by different irrigation techniques. Int. Endod. J. 2014, 47, 659-666. [CrossRef] [PubMed]

33. Bryce, G.; MacBeth, N.; Gulabivala, K.; Ng, Y.L. The efficacy of supplementary sonic irrigation using the EndoActivator ${ }^{\circledR}$ system determined by removal of a collagen film from an ex vivo model. Int. Endod. J. 2018, 51, 489-497. [CrossRef]

34. Al Shahrani, M.; DiVito, E.; Hughes, C.V.; Nathanson, D.; Huang, G.T.J. Enhanced removal of Enterococcus faecalis biofilms in the root canal using sodium hypochlorite plus Photon-Induced Photoacoustic Streaming: An in vitro study. Photomed. Laser Surg. 2014, 32, 260-266. [CrossRef] [PubMed]

35. Olivi, G.; DiVito, E.; Peters, O.; Kaitsas, V.; Angiero, F.; Signore, A.; Benedicenti, S. Disinfection efficacy of photon-induced photoacoustic streaming on root canals infected with Enterococcus faecalis: An ex vivo study. J. Am. Dent. Assoc. 2014, 145, 843-848. [CrossRef] [PubMed]

36. Balić, M.; Lucić, R.; Mehadžić, K.; Bago, I.; Anić, I.; Jakovljević, S.; Plečko, V. The efficacy of photon-initiated photoacoustic streaming and sonic-activated irrigation combined with QMix solution or sodium hypochlorite against intracanal E. faecalis biofilm. Lasers Med. Sci. 2016, 31, 335-429. [CrossRef]

37. Sabins, R.A.; Johnson, J.D.; Hellstein, J.W. A comparison of the cleaning efficacy of short-term sonic and ultrasonic passive irrigation after hand instrumentation in molar root canals. J. Endod. 2003, 29, 674-678. [CrossRef]

38. Jiang, L.M.; Verhaagen, B.; Versluis, M.; Van Der Sluis, L.W. Evaluation of a sonic device designed to activate irrigant in the root canal. J. Endod. 2010, 36, 143-146. [CrossRef]

39. Topçuoğlu, H.S.; Düzgün, S.; Ceyhanlı, K.T.; Aktı, A.; Pala, K.; Kesim, B. Efficacy of different irrigation techniques in the removal of calcium hydroxide from a simulated internal root resorption cavity. Int. Endod. J. 2015, 48, 309-316. [CrossRef]

40. Vrombaut, T.; Maes, E.; Vrombaut, T.; Maes, E. Evaluation of the Efficacy of Sonic and Ultrasonic Activation of Endodontic Irrgants: A Systematic Review. Master's Thesis, Ghent Univercity, Ghent, Belgium, 2016-2018.

41. Buysse, R. Evaluation of the Efficacy of Sonic and Ultrasonic Activation in Removing a Biofilm Mimicking Hydrogel from a Root Canal Wall Groove in Curved Canals. Master's Thesis, Ghent Univercity, Ghent, Belgium, 2018.

42. De Clercq, A. Evaluation of the Efficacy of Sonic and Ultrasonic Activation in Removing a Biofilm-Mimicking Hydrogel from an Isthmus Model. Master's Thesis, Ghent Univercity, Ghent, Belgium, 2018.

43. Karade, P.; Johnson, A.; Baeten, J.; Chopade, R.; Hoshing, U. Smear Layer Removal Efficacy Using EndoActivator and EndoUltra Activation Systems: An Ex Vivo SEM Analysis. Compend. Contin. Educ. Dent. 2018, 39, 9-12.

44. Pedulla, E.; Genovese, C.; Campagna, E.; Tempera, G.; Rapisarda, E. Decontamination efficacy of photon-initiated photoacoustic streaming (PIPS) of irrigants using low-energy alser settings: An ex vivo study. Int. Endod. J. 2012, 45, 865-870. [CrossRef] 
45. Neelakantan, P.; Cheng, C.Q.; Mohanraj, R.; Sriraman, P.; Subbarao, C.; Sharma, S. Antibiofilm activity of three irrigation protocols activated by ultrasonic, diode laser or Er; YAG laser in vitro. Int. Endod. J. 2014, 48, 602-610. [CrossRef] [PubMed]

46. Cheng, X.; Chen, B.; Qiu, J.; He, W.; Lv, H.; Qu, T.; Yu, Q.; Tian, Y. Bactericidal effect of Er: YAG laser combined with sodium hypochlorite irrigation against Enterococcus faecalis deep inside dentinal tubules in experimentally infected root canals. J. Med. Microbiol. 2016, 65, 176-187. [PubMed]

47. Cheng, X.; Xiang, D.; He, W.; Qiu, J.; Han, B.; Yu, Q.; Tian, Y. Bactericidal effect of EDr: YAG laser-activated sodium hypochlorite irrigation against biofilms of Enterococcus faecalis isolate from canal of root-filled teeth with periapical lesions. Photomed. Laser Surg. 2017, 35, 386-392. [CrossRef] [PubMed]

48. Christo, J.E.; Zilm, P.S.; Sullivan, T.; Cathro, P.R. Efficacy of low concentration of sodium hypochlorite and low-powered Er, Cr: YSGG activated irrigation against an Enterococcus faecalis biofilm. Int. Endod. J. 2016, 49, 279-286. [CrossRef] [PubMed]

49. Dagher, J.; El Feghali, R.; Parker, S.; Benedicenti, S.; Zogheib, C. Postoperative Quality of Life Following Conventional Endodontic Intracanal Irrigation Compared with Laser-Activated Irrigation: A Randomized Clinical Study. Photobiomodul. Photomed. Laser Surg. 2019, 37, 248-253. [CrossRef] [PubMed]

(C) 2019 by the authors. Licensee MDPI, Basel, Switzerland. This article is an open access article distributed under the terms and conditions of the Creative Commons Attribution (CC BY) license (http://creativecommons.org/licenses/by/4.0/). 